\title{
A NOTE FROM THE EDITOR
}

With this issue, the Southern Journal of Criminai Justice has finally arrived at full parity with other journals in the field. Over the past three years, the Journal has introduced abstracts, biographical sketchs of authors, and perfect binding and in this issue, for the first time, justified type (i.e., both right and left margins are even). The Journal continues to accept articles only after they have been recommended (often after revisions) by referees in a blind process. Thus, the Journal is now on a par with the best academic and professional journals in the field in terms of process, content and appearance.

Unfortunately, there is one major problem remaining--finances. For the Journal to continue, it must either be given top priority as a budget expenditure of the Southern Association of Criminal Justice Educators (SACJE) or alternative sources of financing must be found. $\overline{S A C} J E$ President Robert Bagby has a mandate from the membership to seek a solution to the financial crisis and has appointed a committee to solve the problem. To eliminate the immediate crisis, this current expanded issue has been designated a double issue. Therefore the next issue, hopefully published next fall, will be Volume VIII, Number 1, with the Spring 1984 issue being Volume VIII, Number 2.

After years of investment and improvement in the Journal, it is the hope of the editor that our efforts can be salvaged and we can continue to provide a quality product to our members and to the criminal justice community of educators, practitioners and students.

For the first time, the 1982 issues of the Journal will be included in The Criminal Justice Periodical Index. They are also scheduled to be included in all future indexes. Hopefully, there will be an alive and well Journal for indexing in 1983 and 1993.

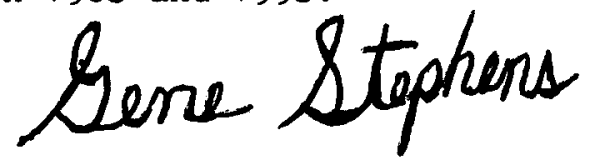

